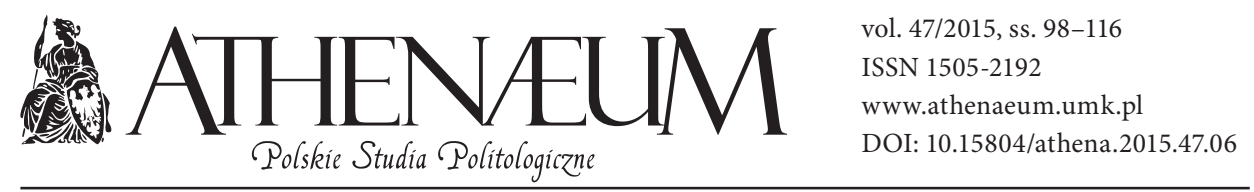

\title{
GENEZA, ZAŁOŻENIA PROGRAMOWE I DZIAŁALNOŚĆ RUCHU PIERESTROJKI W AMERYKAŃSKIEJ NAUCE O POLITYCE
}

\author{
Zbigniew Kantyka*
}

\author{
ORIGINS, CURRICULUM ASSUMPTIONS AND ACTIVITIES \\ OF THE PERESTROIKA MOVEMENT \\ IN AMERICAN POLITICAL SCIENCE
}

\begin{abstract}
Model of methodological and theoretical pluralism, developed after the behavioral revolution, allows different methods and purposes of approach in research of political spheres of social life. For many years, it seemed that the current consensus is not threatened, that the acceptance of the status quo is widespread. As it turned out, however, post-behavioral order and peace were hiding under the surface of old conflicts and contradictions, and generated new ones. Somewhat like 100 years ago, at the beginning of the new century, they flowed on the surface - colliding with each other - as completely different visions of policy research, based on a different meaning of objectivity and truth and the role that the gained knowledge plays in the society.

In October 2000, to a dozen American political scientists and publishers of professional magazines there was sent an e-mail, signed "Mr. Perestroika", containing harsh criticism of the system of forces existing in the American political science, under which there is a strong dominance of representatives of science-oriented mathematical modeling and quantitative methods, and representatives of other approaches are being discriminated against. This letter, commonly called the "Perestroika Manifesto", has rapidly spread in the network, gaining a few hundred followers within a few weeks. It became the nucleus of an informal Perestroika Movement, which brought together a larger group of political scientists dissatisfied with the current model of discipline.
\end{abstract}

* Uniwersytet Śląski w Katowicach, Instytut Nauk Politycznych i Dziennikarstwa. 
They performed against the domination of investigator-driven assumptions of logical positivism and radical behaviorism, based on the assumption that it is possible to predict the political behavior on the basis of the theories of rationality. They also questioned focusing on discovering universal, independent of context, truths about politics, based on testing causal hypotheses with regard to the behavior of political actors and the quest to build a general theory. This results in their opinion that there is the marginalization of other studies aimed at clarifying and resolving specific issues and, on the other hand, the need of search for a more explicit link between theory and practice.

Supporters of the Perestroika Movement do not reject entirely quantitative methods, only tend to criticize their absolutizing character, involving the complete discrediting of approaches which are not referring to the quantification of data or treating this type of treatment only as a complementary knowledge considerations based on normative narrative. Therefore, they generally tend to the concept of methodological triangulation, in which quantitative techniques may complement and partially be a form of verification of qualitative methods in various research issues, of course, if you can combine both types of approaches.

They are clearly in favor of the primacy of the essence of research method. From this point of view, based on compliance with the applicable rules of methodological research, they do not have to be in this respect particularly innovative, hyper-precise or mathematicised. They should, however, contain a well-constructed argumentation, allowing reliably resolve important issues. The result should be to restore compounds research and theoretical knowledge with the real problems of political life, moving away from the extreme containment and academic character towards the relationship of knowledge about politics of social practice.

\section{KEYWORDS}

American political science, behavioralism, methodology, political theory, qualitative methods

W 1969 roku David Easton, przewodniczący Amerykańskiego Stowarzyszenia Nauki o Polityce (American Political Science Association - APSA), w programowym wystąpieniu wygłoszonym na 65 . Kongresie tej organizacji zainicjował koniec ostrej konfrontacji nowego ze starym w teorii i metodologii nauki o polityce, ogłaszając początek ery postbehawioralnej ${ }^{1}$.Ze zrozumieniem odniósł się wówczas do argumentów krytyków radykalnej zmiany spowodowanej

${ }^{1}$ D. Easton, The New Revolution of Political Science, „American Political Science Review” 1969, Vol. 63, No. 4, s. 1051. 
gwałtownym i głębokim behawioralnym zwrotem w koncepcjach i zasadach naukowego poznawania świata polityki. Dostrzegł sens w niezadowoleniu części środowiska naukowego i akademickiego z forsowania badań i nauczania nastawionego na dążenie do przekształcenia politologii w dyscyplinę opartą na bardziej rygorystycznych kryteriach naukowości wzorowanych na naukach przyrodniczych. Zaproponował zawieszenie broni, podkreślając, że w nauce o polityce zorientowanej na przyszłość jest miejsce obok behawioralistów, także dla reprezentantów obu głównych orientacji krytycznych - nurtu tradycyjno-konserwatywnego i reprezentantów nowej lewicy. Dało to początek nowej, pluralistycznej erze w badaniach sfery polityki, która - de facto - trwa do dziś.

Zwrócił on wówczas uwagę, że główną przyczynę potrzeby integracji różnorodnych form poszukiwania prawdy o polityce stanowią społeczne wyzwania epoki: konieczność racjonalnego zmierzenia się z narastającym wyścigiem zbrojeń, postępującą degradacją środowiska naturalnego, kryzysem ekonomicznym, pogłębiającymi się konfliktami społecznymi. W obliczu tej sytuacji, podkreślił, „postbehawioralny ruch w nauce o polityce (i równolegle w innych naukach społecznych) staje w obliczu nowej wizji naszej dyscypliny i obowiązków naszej profesji. Wymaga to podjęcia badań nastawionych na najbardziej istotne kwestie, stworzenia warunków, które zachęcą politologów, w ramach posiadanych przez nich możliwości, do określenia i urzeczywistnienia poprawy jakości życia politycznego zgodnie z kryteriami humanistycznymi”2. D. Easton jednoznacznie przyznał, że błędem była propagowana otwarcie przez behawioralistów ostra dystynkcja między wiedzą a praktycznym działaniem, która zwalniała politologów z obowiązku dokonywania moralnych wyborów związanych z konsekwencjami ich badań i osiąganymi przez nich rezultatami.

Jego wystąpienie stanowiło umiarkowaną odpowiedź ze strony behawioralistów na narastającą radykalną krytykę ich programu i jego praktycznych konsekwencji formułowaną w ramach istniejącego od 1967 roku środowiska Caucus for a New Political Science (CNPS). Członkowie tej frakcji działającej w strukturach APSA głośno wyrażali niezadowolenie z hegemonii zwolenników badań opartych na założeniach metodologicznych wąskiego empiryzmu i pozytywizmu, zwracając uwagę, że tak pojmowana nauka o polityce oddala się od odpowiedzi na kluczowe pytania generowane przez polityczną sferę życia społecznego i traci swój humanistyczny wymiar. Sygnalizowali, że zmiana orientacji metodologicznej drastycznie wpłynęła także na treść i zakres podejmowanej

\footnotetext{
2 Ibidem, s. 1053.
} 
problematyki badawczej, eliminując z obszaru zainteresowań głównego nurtu m.in. takie ważne uwarunkowane politycznie problemy społeczne, jak: zjawiska kryzysowe w środowisku wielkomiejskim, konflikty rasowe, nierówności etniczne i kulturowe czy ubóstwo. Na kongresie APSA w 1968 roku podkreślano, że z prestiżowego pisma „American Political Science Review” (APSR) zniknęły niemal zupełnie opracowania dotyczące tego typu kwestii, a dominują prace oparte na kanonach „twardej nauki”, czyli pozbawione aspektu normatywnego prezentacje uporządkowanych statystycznie danych empirycznych lub abstrakcyjne prace $\mathrm{z}$ zakresu formalnego modelowania ${ }^{3}$.

Wydawało się, że wypracowany wówczas i obowiązujący w kolejnych dekadach konsensus nie jest niczym zagrożony, że akceptacja dla istniejącego status quo jest powszechna. Jak się jednak okazało, ten postbehawioralny ład i pokój ukrywały pod swą powierzchnią dawne konflikty i sprzeczności oraz generowały nowe. Nieco podobnie jak przed 100 laty na początku nowego wieku na powierzchnię wypłynęły, zderzając się ze sobą, całkowicie odmienne wizje badań polityki, oparte na innym rozumieniu obiektywizmu i prawdy oraz roli, jaką uzyskana wiedza ma odgrywać w społeczeństwie.

Celem artykułu jest prezentacja podstawowych argumentów uczestników nowej dyskusji na temat podstaw metodologicznych i teoretycznych nauki o polityce w oparciu o analizę publikowanych przez nich tekstów, ze szczególnym uwzględnieniem Ruchu Pierestrojki (Perestroika Movement), w ramach którego znaleźli miejsce wszyscy zwolennicy postulowanych zmian i reform.

\section{GENEZA}

W październiku 2000 roku do kilkunastu politologów amerykańskich oraz wydawców branżowych czasopism skierowany został e-mail podpisany „Mr. Perestroika”, zawierający ostrą krytykę istniejącego w amerykańskiej politologii układu sił, w ramach którego zdecydowanie dominują reprezentanci nauki zorientowanej na modelowanie matematyczne i metody ilościowe, a przedstawiciele innych podejść są dyskryminowani. List ten, nazwany potocznie „Mani-

${ }^{3}$ Por. I. Oren, Our Enemies and Us: America's Rivalries and the Making of Political Science, Ithaca 2003, s. 162. 
festem Pierestrojki" (Perestroika Manifesto) ${ }^{4}$, błyskawicznie rozprzestrzenił się w sieci, zyskując w ciągu kilku tygodni kilkuset zwolenników ${ }^{5}$. Zawarta w nim ostra krytyka dotyczyła m.in. układu władzy w APSA, wskazując, że organizacja ta zdominowana jest przez personalne koterie. Autor negatywnie oceniał również profil merytoryczny tekstów zamieszczanych w firmowanych przez stowarzyszenie czasopismach. Nazbyt ostre kryteria naukowości eliminują bowiem wartościowe propozycje publikacji opartych na tradycyjnym podejściu historycznym, jakościowych studiach konkretnych przypadków i antyredukcjonistycznej krytycznej analizie kontekstualnej. Zwrócił uwagę, że poza zainteresowaniami APSA znalazł się spory obszar typowo politologicznych problemów badawczych, głoszone powszechnie zróżnicowanie metodologiczne ma charakter jedynie pozorny, a wielu wybitnych politologów mniej lub bardziej wprost dystansuje się od działań organizacji. Nie publikuje się prac dotyczących historii politycznej, socjologii politycznej, metodologii interpretacyjnej, konstruktywizmu, studiów regionalnych, teorii krytycznej czy postmodernizmu. Zastępują je wątpliwej wartości prace bazujące na schematycznych ujęciach pseudoekonomicznych, statystyce i teorii gier. „Mam nadzieję - stwierdził w ostatnim zdaniu Mr. Perestroika - że ten anonimowy list doprowadzi do demontażu Orwellowskiego systemu, który istnieje w APSA i tym samym nastąpi prawdziwa pierestrojka w naszej dyscyplinie" 6 .

Jeszcze w tym samym roku kilkudziesięciu politologów skierowało list otwarty do władz i członków APSA ${ }^{7}$. Jego autorzy, podpisując się imiennie pod tezami Mr. Perestroiki, rozszerzyli stawiane przez niego pytania i problemy, podkreślając, że tę bardzo subiektywną anonimową wypowiedź poparła zadzi-

4 The Idea. The Opening of Debate. Perestroika, [w:] Perestroika! The Raucous Rebelion in Political Science, red. K.R. Monroe, New Haven-London 2005, s. 9-11.

5 Zob. E. Eakin, Political Scientists Leading a Revolt, Not Studying One, „The New York Times”, 4.10.2000; S. Steinmo, Perestroika/Glasnost and „Taking Back the APSR”, „The New York Times”, 4.10.2000; S. Heller, D.W. Miller, 'Mr. Perestroika' Criticizes Political Science Journal's Methodological Bias, „Chronicle of Higher Education”, 17.10.2000; D.W. Miller, Storming the Palace in Political Science, "Chronicle of Higher Education", 21.08.2001; J. Blecher, Forward the Revolution: How One E-Mail Shook Up the Political Science Establishment, „New Journal”, Yale University 2001, No. 34, s. 18-23; R.M. Smith, Putting the Substance Back in Political Science, „Chronicle of Higher Education”, 5.04.2002, s. 10-11; How Cult Internet Character Mr. Perestroika Divided N.Y.U.'s Political Science Department, „New York Observer”, 7.01.2002, s. 3.

6 The Idea, op.cit., s. 11.

7 C.S. Allen [et. al.], An Open Letter to the APSA Leadership and Members, „PS: Political Science \& Politics" 2000, Vol. 33, No. 4, s. 735-737. 
wiająca liczba uczonych, zajmujących różne pozycje wewnątrz środowiska. Odczuli oni potrzebę wyrażenia swego stanowiska i ogłoszenia, że podzielają głębokie niezadowolenie $\mathrm{z}$ obowiązującego stanu rzeczy. W liście padł zarzut nadmiernej koncentracji na technicznej stronie badań kosztem jakości podejmowanych kwestii. Za ewidentny skutek uboczny tego stanu rzeczy uznano oddalanie się od zrozumienia sensu zjawisk i procesów politycznych oraz coraz większą alienację formułowanej w ten sposób wiedzy z życia społecznego. Zwrócono uwagę na spadek zainteresowania lekturą APSR (zwłaszcza od momentu, gdy jego prenumerata dla członków APSA przestała być obowiązkowa), co związane jest z zamknięciem się programowym pisma na teksty wielu autorów oraz z brakiem dostatecznie demokratycznych procedur wyłaniania redakcji i kierownictwa pisma. List stał się formalnym zalążkiem nowego ruchu. „Nie stanowimy zorganizowanej, opartej na regularnej rekrutacji grupy - pisali sygnatariusze listu. Jesteśmy po prostu uczonymi, którzy po krótkiej dyskusji nad listem Mr. Perestroiki postanowili się do niego przyłączyć. Czynimy tak, ponieważ jesteśmy przekonani, że nasza profesja podąża w stronę alienacji coraz większej liczby tych, którzy chcieliby odgrywać w jej ramach aktywną rolę, oraz dostarcza coraz mniej możliwości zrozumienia polityki, a to jest sprzeczne z naszą odpowiedzialnością za postęp"8.

Ostre dysproporcje w praktycznej realizacji metodologicznego i teoretycznego pluralizmu znalazły potwierdzenie w systematycznych analizach zawartości głównych amerykańskich fachowych czasopism politologicznych, które potwierdziły drastyczny spadek publikacji opartych na badaniach jakościowych na rzecz artykułów bazujących na metodach statystycznych, matematycznych i modelach formalnych ${ }^{9}$. Z niepokojem odnotowywano również fakt, że w środowisku akademickim istnieje silny mechanizm polegający na reprodukowaniu tego typu badań, oparty na motywowaniu ekonomicznym (stypendia, dobra praca) i presji intelektualnej wywieranej na studentów i doktorantów. Sprawia to, że dokonując wyboru tematów badań i metodologii, kierują się oni względami pragmatycznymi i życiowymi, odrzucając mało atrakcyjne z tego punktu widzenia opcje, nawet

8 Ibidem.

9 Zob. D. Yanow, Practicing Discipline, „PS: Political Science \& Politics” 2003, Vol. 36, No. 3, s. 397; D. Pion-Berlin, D. Cleary, Methodological Bias in the APSR, [w:] Perestroika!, op.cit., s. 304-322; L. Sigelman, The Coevolution of American Political Science and the American Political Science Review, „American Political Science Review” 2006, Vol. 100, No. 4. 
jeśli bardziej odpowiadają one ich naukowym pasjom i zainteresowaniom ${ }^{10}$. Potwierdza to fakt, że wielu młodych politologów, doktorantów i asystentów, zgłaszając swój akces do Ruchu Pierestrojki, w ramach dyskusji internetowej sygnalizowało obawy przed ujawnieniem własnej tożsamości i związanymi z tym konsekwencjami ${ }^{11}$.

Podstawowym źródłem wiedzy na temat motywów działania, założeń Ruchu i jego celów stał się obszerny tom Perestroika! The Raucous Rebelion in Political Science opublikowany w 2005 roku pod redakcją Kristen Renwick Monroe przez wydawnictwo Uniwersytetu Yale ${ }^{12}$.Zebrane zostały w nim kluczowe, rozproszone dotąd, wypowiedzi zwolenników orientacji, nowe teksty programowe, próbujące nadać Ruchowi Pierestrojki uporządkowane ramy, przykłady badań inspirowanych nowymi ideami oraz pojedyncze wypowiedzi przeciwników i krytyków. W jednej z opinii zamieszczonych na okładce książki D. Easton określił ją jako „pasjonujący, prowokujacy zbiór esejów o źródłach, zakresie, znaczeniu, ograniczeniach i konsekwencjach Ruchu Pierestrojki, który ukazuje dyscyplinę jako dynamiczne, żywe i krytyczne poszukiwanie różnych sposobów zrozumienia i racjonalizacji życia politycznego" ${ }^{13}$.

\section{METODY}

Jednymi z podstawowych założeń metodologicznych Ruchu stały się krytyka dominacji badań inspirowanych założeniami logicznego pozytywizmu i skrajnego behawioralizmu, opartych na założeniu, że możliwe jest przewidywanie zachowań politycznych w oparciu o teorie racjonalności, i negatywna ocena poglądu, że podążanie w tym właśnie kierunku jest gwarancją rozwoju rzeczywistej wiedzy o polityce. Celem podstawowym w ramach tego dominującego paradygmatu jest odkrywanie uniwersalnej, niezależnej od kontekstu, prawdy o polityce, opartej na testowaniu hipotez przyczynowych w odniesieniu do zachowań aktorów politycznych i budowie teorii ogólnej. Powoduje to marginalizację

10 T. Pachirat, We Call It Grain of Sand. The Interpretive Orientation and a Human Social Science, [w:] Interpretation and Method: Empirical Research Methods and the Interpretive Turn, red. D. Yanow, P. Schwartz-Shea, Armonk-London 2006, s. 373.

11 D. Yanow, Neither Rigorous Nor Objective? Interrogating Criteria for Knowledge Claims in Interpretive Sciences, [w:] Interpretation And Method, op.cit., s. 88.

12 Perestroika!, op.cit. Na tom złożyły się prace 38 autorów.

13 Ibidem. 
innych badań nastawionych na wyjaśnianie i rozwiązywanie konkretnych kwestii oraz poszukiwanie bardziej wyraźnego związku między teorią i praktyką ${ }^{14}$.

Zwolennicy Ruchu Pierestrojki nie odrzucają całkowicie metod ilościowych, krytykują jedynie tendencję do ich absolutyzacji, polegającą na całkowitym dyskredytowaniu wartości ujęć nieodwołujących się do kwantyfikacji danych lub też traktujących tego typu zabiegi jedynie jako wiedzę uzupełniającą rozważania oparte na narracji normatywnej. Skłaniają się więc na ogół do koncepcji triangulacji metodologicznej, w ramach której techniki ilościowe mogą stanowić uzupełnienie i częściową weryfikację metod jakościowych, jeśli oczywiście problematyka badawcza pozwala na łączenie obu typów podejść.

Jednoznacznie opowiadają się oni za prymatem istoty badań nad metodą. Przestrzeganie reguł i logiki wyjaśniania ma być zawsze podporządkowane „dystynktywnemu wglądowi w istotę politycznych kwestii” ${ }^{15}$. Z tego punktu widzenia oparte na przestrzeganiu obowiązujących zasad metodologicznych badania nie muszą być pod tym względem wyjątkowo nowatorskie, hiperprecyzyjne czy zmatematyzowane. Powinny jednak zawierać dobrze skonstruowaną argumentację, pozwalając wiarygodnie rozstrzygać ważne kwestie. Prowadzi to do postulatu uzupełnienia, a często wręcz zastąpienia badań nastawionych na metody badaniami ukierunkowanymi na problemy ${ }^{16}$.

Skrajnie sceptyczny stosunek zajmują uczestnicy ruchu do teorii racjonalnego wyboru, określanych przez nich złośliwie terminem rat choice (zamiast oryginalnego rational choice), co oczywiście odzwierciedla krytykę behawiorystycznych źródeł i konsekwencji tego podejścia oraz przekonanie o jego nieadekwatności w odniesieniu do skomplikowanej struktury i mechanizmów życia społecznego. Ostrze krytyki wymierzone jest m.in. w Williama H. Rikera i szkołę Rochester, najbardziej wpływowy nurt tzw. pozytywnej teorii polityki, zorientowanej na metody formalne i kwantyfikację danych ${ }^{17}$. Z punktu widzenia zwolenników Ruchu Pierestrojki teorie racjonalnego i publicznego wyboru, których reprezentantów, zwłaszcza w naukach ekonomicznych, uhonorowano licznymi Nagrodami Nobla, w rzeczywistości opisują fikcyjny świat, abstrahując od rzeczywistych mechanizmów zachowań ludzkich i społecznych. Uniwersalny

14 S.F. Schram, Return to Politics: Perestroika and Postparadigmatic Political Science, „Political Theory" 2003, Vol. 31, No. 6, s. 836.

15 R.M. Smith, op.cit., s. 10.

16 I. Shapiro, What's Wrong with Political Science and What to Do About It, „Political Theory” 2002, Vol. 30, No. 4, s. 596-619.

17 Por. G. Mackie, Democracy Defended, Cambridge 2003, s. 24-26. 
człowiek wymodelowany na hiperracjonalnego homo œeconomicus zostaje niemal całkowicie wypreparowany z otaczającej go rzeczywistości, oderwany od kultury, osobowości, autorefleksji, emocjonalności, spontaniczności i innych „zakłóceń”, które mogłyby zaburzyć czystość i przejrzystość formalnej konstrukcji.

Tego typu krytyczne poglądy napotykają ostry opór ze strony wielu reprezentantów dominującego postbehawioralnego nurtu w politologii, którzy bronią ortodoksyjnej pozytywistycznej formuły naukowości, negując wszystko, co poza nią wykracza. Liderem tego typu poglądów, najbardziej aktywnym w polemice ze zwolennikami Ruchu Pierestrojki, jest David Laitin, reprezentujący ekonomiczny wariant teorii racjonalnego wyboru, który określił ich mianem luddytów przestraszonych współczesną nauką. W tomie podsumowującym pierwszy okres działania Ruchu pisał krytycznie: „Granice naukowości pozwalałyby przypuszczać, że pewne obszary wiedzy są już dzisiaj martwe, pewne debaty zakończone, a pewne metody przestarzałe. Pluralizm, który daje schronienie tym zapomnianym praktykom, nie może być naukowo usprawiedliwiony"18.

Ważnym punktem inspiracji i odniesienia dla uczestników ruchu pozostaje program metodologiczny sformułowany w opublikowanej poza głównym nurtem dyskusji politologicznej pracy Benta Flyvbjerga Making Social Science Matter: Why Social Inquiry Fails and How It Can Succeed Again ${ }^{19}$. Autor zaproponował w niej radykalne odejście od prób oceniania wartości badań i wiedzy społecznej przez pryzmat kryteriów typowych dla nauk przyrodniczych - wiedzy naukowej (episteme) i specjalistycznej wiedzy technicznej (techné). Podstawę nauk społecznych powinno stanowić kontrastujące z nimi pojęcie mądrości życiowej (phronesis). Siła nauk przyrodniczych polega na budowie teorii wyjaśniających i przewidujących, co jest istotne, ponieważ przedmiot ich badań nie może się sam tłumaczyć, albo zmieniać zamiarów w następstwie strategii retorycznych. W tym zakresie nauki społeczne nie mogą im dorównać. Ich zadanie jest inne, ma naturę hermeneutyczną i musi uwzględnić fakt, że poznanie świata ludzkiego jest uwikłane w rozumienie i interpretację (zarówno po stronie tego, który bada, jak i tego, który jest badany) ${ }^{20}$.

18 D.M. Laitin, The Perestroikan Challenge to Social Science, [w:] Perestroika!, op.cit., s. 132. Ta ostra krytyka postulatów Ruchu Pierestrojki nie pozostała oczywiście bez odpowiedzi ze strony jego zwolenników - zob. B. Flyvbjerg, A Perestroikan Straw Man Answers Back: David Laitin and Phronetic Political Science, „Politics and Society” 2004, Vol. 32, No. 3, s. 389-416; L.I. Rudolph, S.H. Rudolph, Economics' Fall from Grace, „PS: Political Science \& Politics” 2010, Vol. 43, No. 4, s. 747-748.

19 B. Flyvbjerg, Making Social Science Matter: Why Social Inquiry Fails and How It Can Succeed Again, Cambridge 2001.

20 Ibidem, s. 32-33. 
Przeniesieniem propozycji B. Flyvbjerga bezpośrednio na grunt politologii w połączeniu z programem Ruchu Pierestrojki stała się praca pod redakcją Sanforda F. Schrama i Briana Caterino Making Political Science Matter. Debating Knowledge, Research and Method z 2006 roku $^{21}$. Zamieszczone w niej teksty, na ogół publikowane wcześniej w różnych czasopismach naukowych, a więc znane i stanowiące fragment toczącej się dyskusji, zawierały rozwinięcie wielu zgłaszanych od początku przez uczestników Ruchu Pierestrojki propozycji metodologicznych, pogłębionych i osadzonych w kontekście tzw. Flyvbjerg debate. Jednym z elementów refleksji stała się próba identyfikacji wspólnych, mimo odmienności sytuacji w USA i w Europie, celów związanych z konieczną przebudową badań społecznych. Sytuacja politologii europejskiej zasadniczo różniła się od amerykańskiej - mimo pewnego wzrostu zainteresowania i rozwoju badań ilościowych siłą tradycji dominowały publikacje oparte na badaniach jakościowych ${ }^{22}$. Związane było to m.in. ze zdecydowanie łagodniejszym niż w USA przebiegiem rewolucji behawioralnej, która oczywiście pozostawiła po sobie wyraźne ślady, lecz jej zwolennicy nigdy nie osiągnęli tak dominującej pozycji jak po drugiej stronie oceanu ${ }^{23}$. Mimo tej różnicy wspólne stało się dążenie do rezygnacji ze skrajnie naturalistycznego wzorca, jako jedynego miernika naukowości, i otwarcie przestrzeni dla podejść alternatywnych, bowiem one istniały, istnieją i zawsze będą istnieć ${ }^{24}$. Stąd, jak podkreślają redaktorzy tomu, „podejścia interpretacyjne, które kładą nacisk na rozumienie znaczenia społecznego działania w określonych kontekstach, zyskują na znaczeniu w badaniach społecznych. Poszukiwanie tego typu wyjaśnień jest coraz bardziej skuteczne. Dla rosnącej liczby specjalistów z zakresu nauk społecznych trudne jest wyobrażenie sobie czystego faktu społecznego, niezależnego od kontekstu czy znaczenia. Czy polityczny przywódca, na przykład, mógłby mieć przekonanie o prawomocności swego działania

${ }^{21}$ Making Political Science Matter. Debating Knowledge, Research and Method, red. S.F. Schram, B. Caterino, New York-London 2006.

22 Por. L. Billordo, Methods Training in French Political Science, „French Politics” 2005, No. 3 , s. 352-357; L. Hooghe, Letter from the Chair: Methodological Pluralism among Europeanists, „APSA European Politics \& Society Newsletter" 2005, Vol. 4, No. 2, s. 1; J. Jupille, A Thousand Flowers Blooming? Methodological Practices in EU Studies, „APSA European Politics \& Society Newsletter” 2005, Vol. 4, No. 2, s. 2-6; M. Rhodes, J. Newell, Editorial, „European Political Science” 2006, Vol. 5, s. $107-109$.

23 B. Caterino, S.F. Schram, Introduction. Reframing the Debate, [w:] Making Political Science Matter, op.cit., s. 2; C. Kinnvall, Not Here, Not Now! The Absence of a European Perestroika Movement, [w:] Perestroika!, op.cit., s. 21-44.

24 B. Caterino, S.F. Schram, op.cit., s. 5. 
niezależnie od poparcia politycznego zaplecza, które je legitymizuje? Rośnie liczba badaczy akceptujących przekonanie, że wiedza o społecznym świecie jest niemożliwa bez rozumienia sensu działania współuczestników społecznego świata" ${ }^{25}$. Zaczerpnięte z terminologii Arystotelesowskiej pojęcie phronesis i pomysł, by skierować nauki społeczne w tę właśnie stronę, oznaczają nie zaprzeczenie czy odrzucenie abstrakcyjnych i uniwersalnych episteme i techné, lecz postulat uzupełnienia wiedzy społecznej o wartości i właściwości, bez których staje się ona bezużyteczna. W przypadku nauki o polityce, aby nadać jej rzeczywiste znaczenie, trzeba podjąć próbę odpowiedzi na pytanie: dokąd zmierzamy? Jeśli je zignorujemy lub nie uda nam się na nie skutecznie odpowiedzieć, pozostaniemy w liberalnym i demokratycznym społeczeństwie skazani - jak dotąd - na wiarę w techniczne rady ekspertów i koncepcje biznesmenów, wskazujących to, co rzekomo jest najlepsze dla wspólnego dobra ${ }^{26}$.

\section{TEORIA}

W centrum krytycznej refleksji Ruchu Pierestrojki na temat stanu współczesnej nauki o polityce znalazły się nie tylko kwestie czysto metodologiczne, ale także - a może przede wszystkim - treść i funkcje wiedzy naukowej. Obie te kwestie jego uczestnicy postrzegali zresztą w ścisłym związku ze sobą, akcentując jednak przede wszystkim uzależnienie kierunku i jakości refleksji teoretycznej od dominacji określonych rozstrzygnięć metodologicznych. Poruszając zagadnienie funkcji nauki, podobnie jak w radykalnej krytyce końca lat sześćdziesiątych, sygnalizowali poczucie drastycznego oderwania sformalizowanych badań i analiz statystycznych, logicznych i matematycznych od rzeczywistego życia społecznego, od realnych pytań, na które trzeba odpowiadać, i problemów, które trzeba rozwiązywać w sferze polityki. Paradygmat krytykowany przez uczestników Ruchu Pierestrojki - w ujęciu S.F. Schrama - opiera się następujących założeniach: (1) zadaniem politologii jest działanie na rzecz zrozumienia prawdy o polityce; (2) badania politologiczne przyczyniają się do tego poprzez gromadzenie i poszerzanie obiektywnej wiedzy o polityce; (3) wzrost tej wiedzy jest zależny od budowy teorii, której funkcją jest wyjaśnianie polityki; (4) tworzenie teorii

25 Ibidem, s. 7.

26 T.W. Luke, Finding New Mainstreams. Perestroika, Phronesis, and Political Science in the United States, [w:] Making Political Science Matter, op.cit., s. 257. 
jest uwarunkowane rozwojem uniwersalnych generalizacji dotyczących zachowania aktorów politycznych; (5) rozwój rosnącej bazy uogólnień następuje przez testowanie falsyfikowanych hipotez przyczynowych, które muszą potwierdzać się poprzez skuteczność przewidywań; (6) rosnąca skuteczność przewidywań dotyczących zachowania politycznego wynika $\mathrm{z}$ analiz zmiennych opartych na próbach obejmujących duże liczby przypadków; (7) te rosnące zasoby obiektywnej, przyczynowej wiedzy mogą być wykorzystane w służbie społeczeństwu poprzez wpływ na decydentów publicznych i działaczy państwowych ${ }^{27}$. Tak zdefiniowane granice naukowości badań nad polityką, zdaniem zwolenników Ruchu Pierestrojki, wyłączają wiele poważnych badań, np. opartych na studium przypadku i innych metodach jakościowych, a ich skuteczność i przydatność praktyczna budzą poważne wątpliwości.

Intencją uczestników Ruchu stało się przywrócenie nauce o polityce wymiaru dyscypliny operującej perspektywą krytyczną, podejmującej kluczowe kwestie generowane przez życie społeczne i nastawionej na rozwiązywanie w oparciu o wiedzę pojawiających się realnych problemów. Oznacza to zerwanie z wizerunkiem nauki zorientowanej wyłącznie na wiedzę samą w sobie na rzecz dziedziny, w której rolę kluczową odgrywa osadzona w szerszej perspektywie refleksja krytyczna ${ }^{28}$.

Propozycja przywrócenia związku poszukiwań naukowych z praktyką polityczną, nie na poziomie czysto instrumentalnym (bierne techniczne doradztwo), lecz w znaczeniu rozwiązywania rzeczywistych problemów, jest bliska niemal wszystkim zwolennikom Ruchu Pierestrojki. Jak to ujął S.F. Schram, „Pierestrojka jest luźnym ruchem politologów, począwszy od słuchaczy studiów magisterskich aż po starszych wykładowców, którzy nie zawsze zgadzając się całkowicie ze sobą co do metody, wspólnie odczuwają brak w politologii podejścia krytycznego. Dostrzegają zbyt abstrakcyjną naturę znacznej części badań, ich dekontekstualizację, koncentrację na odpowiedniej skali empirycznej próby, dehumanizację myślenia o relacjach społecznych. Tak uprawiane współczesne nauki społeczne

27 S.F. Schram, Return to Politics: Perestroika and Postparadigmatic Political Science, op.cit., s. 836.

28 Tak postrzegana jest istota programu Ruchu Pieriestrojki z perspektywy innych dyscyplin, które borykają się z nieco podobnymi problemami. Jego odpowiednikiem w socjologii jest program tworzenia „socjologii publicznej” - por. M. Burawoy, The Critical Turn to Public Sociology, [w:] Enriching the Sociological Imagination: How Radical Sociology Changed the Discipline, red. R.F. Levine, Boston 2004, s. 314-315, a w ekonomii, zainicjowany w podobnym czasie, europejski ruch Post-Autistic Economics (PAE) - zob. Real World Economics: A Post-Autistic Economics Reader, red. E. Fullbrook, London 2007. 
zwykle nie potrafią wytworzyć wiedzy, która mogłaby znacząco przenikać życie społeczne" 29 .

Proponując $\mathrm{w}$ miejsce naśladowania nauk przyrodniczych skierowanie się $\mathrm{w}$ stronę tworzenia fronetycznej nauki o polityce (phronetic political science), B. Flyvbjerg podkreślił, że głównym celem powinno być analizowanie i tworzenie interpretacji wartości i interesów w praktyce politycznej i administracyjnej. Założenie to można sprowadzić do czterech racjonalno-wartościujących pytań: 1) Dokąd zmierzamy?; 2) Kto zyskuje, a kto traci i w jakim to pozostaje związku z mechanizmami władzy?; 3) Czy słuszny jest rozwój w tym kierunku?; 4) Co, jeśli w ogóle, powinniśmy w tej sytuacji zrobić? ${ }^{30}$ Poszukująca odpowiedzi na nie nowa, zmodernizowana nauka o polityce powinna być krytyczna, użyteczna i podporządkowana celom społecznym, czyli - jak określiły to wprost Dvora Yanow i Peregrine Schwartz-Shea, nie wstydząc się tego terminu - powinna być nauką zaangażowaną (engaged) ${ }^{31}$.

Susanne H. Rudolph, podejmując zagadnienie kierunków rozwoju wiedzy politologicznej, zwróciła uwage na konieczność odejścia od jednostronnego zapatrzenia w paradygmat poszukiwania uniwersalnej teorii ogólnej. Zasadniczym błędem było poszukiwanie odpowiedzi na nurtujące naukę o polityce pytania odnoszące się do wszystkich społeczeństw w oparciu o zabarwioną ideologicznie perspektywę amerykańskiego liberalizmu. Stanowiący podstawę tego modelu uniwersalizm Locke’a wygenerował nadmierną wiarę w możliwość interpretowania i wyjaśniania funkcjonowania różnych społeczeństw za pomocą jednorodnego schematu opartego na kategorii racjonalności, co prowadziło na ogół do przypisywania im motywów zgodnych z ogólną teorią, bez ich rzeczywistej weryfikacji. Jej zdaniem „przypuszczenie, że preferencje i wybory aktorów są zdeterminowane wyłącznie przez kalkulację opartą na własnym racjonalnym interesie, jest problematyczne nie tylko dlatego, że ignoruje rolę sentymentów, namiętności i zaangażowania, nie tylko dlatego, że racjonalność jest raczej wyjątkiem niż regułą, lecz głównie z powodu tego, że nie uwzględnia niejednorodnego uwarunkowania zachowania przez zróżnicowane kultury”. Alternatywę powinna stanowić „wiedza usytuowana” (situated knowledge), zrywająca z koncepcjami racjonalnego wyboru i opartymi na anglo-amerykańskich wzorcach i kategoriach

29 S.F. Schram, Return to Politics. Perestroika, Phronesis, and Post-Paradigmatic Political Science, [w:] Making Political Science Matter, op.cit., s. 18.

30 B. Flyvbjerg, A Perestroikan, op.cit., s. 76.

31 D. Yanow, P. Schwartz-Shea, Re-recognizing Interpretive Methodologies in the Human Sciences, [w:] Interpretation and Method, op.cit., s. 369. 
studiami dotyczącymi globalizacji. Wiedza tego typu uwzględnia czas, miejsce i uwarunkowania oraz zakłada, że czynniki te wywierają wpływ na badane jednostki i społeczności. Teoria konstruowania „wiedzy usytuowanej” bierze pod uwagę lokalną wiedzę i praktykę oraz sposób postrzegania i interpretowania rzeczywistości przez badanych. To strategia budowy teorii od dołu, a nie od góry. Ten typ wiedzy, w odróżnieniu od wiedzy uniwersalnej, nie zakłada jednakowej drogi rozwojowej dla całej ludzkości, lecz przewidywania dotyczące przyszłości odnosi do konkretnych kultur i społeczeństw, których wiedza ta dotyczy ${ }^{32}$.

\section{ORGANIZACJA/STRUKTURA}

Zwolennicy ruchu poddali ostrej krytyce istniejące mechanizmy wyborcze w APSA, zwracając uwagę na potrzebę zwiększenia wpływu na nominację kandydatów marginalizowanym dotąd grupom mniejszościowym pozostającym poza głównymi nurtami, dominującymi od lat w Stowarzyszeniu. Uzasadniali to, odwołując się do argumentu, że trudno zaakceptować sytuację, w której instytucja propagująca demokrację społeczną i polityczną sama w swym działaniu ewidentnie oddala się od zasad równości i egalitaryzmu.

Propozycje te nie były powszechnie akceptowane. Argumenty przeciwników znalazły odzwierciedlenie m.in.w opozycyjnym do wystąpienia Mr. Perestroiki, również anonimowym e-mailu, który pojawił się w sieci internetowej w czerwcu 2002 roku, sygnowanym „Mr. Pravda”. Jego autor zarzucił zwolennikom Ruchu Pierestrojki m.in., że za ich reformatorskimi propozycjami kryją się czysty koniunkturalizm i chęć ominięcia koniecznych rygorów metodologicznych, aby móc łatwiej publikować własne teksty i robić własne kariery naukowe i organizacyjne. Potwierdzać to miał eklektyzm ideologiczny Ruchu, w którym mieściły się tak skrajne nurty, jak: reprezentanci tradycyjnej politologii chrześcijańsko-konserwatywnej ze szkoły Leo Straussa, lewicowi postmoderniści czy przedstawiciele politologii feministycznej ${ }^{33}$.

Blisko 15 lat istnienia Ruchu Pierestrojki przyniosło korzystne zmiany w strukturze i mechanizmach funkcjonowania APSA, stwarzając tym samym

32 S.H. Rudolph, The Imperialism of Categories: Situating Knowledge in a Globalizing World, „Perspectives on Politics” 2005, Vol. 3, No. 1, s. 5-14.

${ }_{33} \mathrm{Mr}$ Pravda, Some Thoughts on Perestroika and Political Science, http://h-net.msu.edu, odczyt $\mathrm{z}$ dn. 5.10.2014. 
szanse na wprowadzenie reform merytorycznych, uzależnionych od decyzji i polityki władz organizacji. Nie wszystkie propozycje udało się przeforsować jego zwolennikom i przekształcić w obowiązujące reguły statutowe. O rosnącej pozycji nurtu reformatorskiego świadczy jednak fakt, że w latach 2002-2003 prezydentem APSA była sympatyzująca $z$ ruchem Theda Skocpol (Uniwersytet Harvarda), a tuż po niej w latach 2003-2004 tę funkcję objęła jedna z czołowych jego przedstawicielek S. H. Rudolph (Uniwersytet Chicago). Kilka innych osób związanych $\mathrm{z}$ Ruchem Pieriestrojki w tym okresie zaczęło odgrywać również istotną rolę w strukturach organizacyjnych. Istotny wpływ na to miał Robert Putnam (prezydent APSA w latach 2001-2002), który dopuścił zwolenników Ruchu do wielu ważnych funkcji decyzyjnych w Stowarzyszeniu. Zdecydowanie wzrosła pozycja badaczy niemieszczących się w krytykowanej przez Ruch Pierestrojki politologii neobehawioralnej.

Znaczny postęp nastąpił także $\mathrm{w}$ treści publikacji zamieszczanych w APSR, głównie za sprawą nowego redaktora pisma Lee Siegelmana ${ }^{34} \mathrm{~W}$ latach 2002-2004 na łamach tego kwartalnika ukazało się dwa razy więcej artykułów opartych na badaniach jakościowych niż w ciągu całej wcześniejszej dekady ${ }^{35}$. Niewątpliwym sukcesem Ruchu było przyspieszenie prac nad uruchomieniem nowego, bardziej otwartego metodologicznie i teoretycznie pisma wydawanego przez APSA. Już w marcu 2003 roku ukazał się wydany przez Cambridge pod patronatem Stowarzyszenia pierwszy numer „Perspectives on Politics”36. Jego redaktor naczelną została specjalizująca się w badaniach procesów rządzenia i zagadnień etnicznych Jennifer Hochschild z Uniwersytetu Harvarda. Obejmując tę funkcję, zapowiedziała, że pismo będzie starało się objąć swym zakresem całość problematyki badawczej politologii, od kontemplacyjnej filozofii polityki, interpretacyjnych studiów przypadku i analiz dotyczących polityk szczegółowych, które wywołują często polityczne spory, po systematyczne badania ilościowe oraz prace oparte na metodach dedukcyjnych. Wszystkie te obszary nie powinny bowiem się wykluczać, lecz wzajemnie wspierać i uzupełniać. Od strony programowej pismo wybrało strategię poruszania się po cienkiej granicy między tym, co aktualne i ważne, a zagadnieniami mieszczącymi się w ramach czysto akademickiej naukowości. Oznaczało to położenie nacisku na dwie tendencje:

${ }^{34}$ L. Sigelman, The APSR in the Perestroikan Era, [w:] Perestroika!, op.cit., s. 323-329.

35 Zob. K. Jacobsen, Perestroika in American Political Science, „Post-Autistic Economics Review” 2005, No. 32, Article 6, http://www.paecon.net/PAEReview/issue32/Jacobsen32.htm, odczyt z dn. 5.10.2014.

36 J. Hochschild, Inventing Perspectives on Politics, [w:] Perestroika!, op.cit., s. 330-341. 
z jednej strony odejście od artykułów bardzo wąsko specjalistycznych, z drugiej przestrzeganie zasad rzetelności naukowej i zrozumiałości dla odbiorców ${ }^{37}$.

Postulat większego dostępu do ważnych stanowisk dla reprezentantów różnych grup etnicznych, kulturowych i płci stanowił ważne hasło programowe zwolenników Ruchu Pierestrojki, podnoszone od początku ich aktywności (ostro zasygnalizowane już bezpośrednio w inicjującym Ruch e-mailu Mr. Perestroiki ${ }^{38}$ ). Od momentu powstania Ruchu z kolejnych pięciu prezesów APSA, czterech było kobietami, co nie zdarzało się nigdy wcześniej w długiej, ponad stuletniej historii organizacji.

W 2003 roku powstała w strukturze APSA nowa Sekcja Metod Jakościowych, utworzono również międzyuniwersyteckie Konsorcjum Jakościowych Metod Badawczych, organizujące dorocznie konferencje metodologiczne poświęcone tej orientacji w badaniach politologicznych ${ }^{39}$.

Postulaty i działania Ruchu Pierestrojki nie zdołały zmienić negatywnych zjawisk kadrowych w amerykańskiej politologii, której pozycja w środowisku akademickim stopniowo się osłabia - spadają liczba naukowców zatrudnionych na stałych etatach oraz liczba studentów. Wielu politologów działa indywidualnie, pozostając w izolacji, nie mając stałych związków z uczelniami. Jest to rezultat m.in. rosnących opłat za studia przy jednoczesnym zmniejszaniu się uposażeń nauczycieli akademickich. APSA nie reaguje na te zjawiska odpowiednio aktywnie, ma zresztą mocno ograniczone możliwości zapobiegania tym negatywnym tendencjom. Niemniej jednak wzrosło zainteresowanie Stowarzyszenia zagadnieniami edukacji, czego świadectwem stało się organizowanie coraz większej liczby sympozjów i konferencji poświęconych kwestiom dydaktyki w ramach studiów politologicznych ${ }^{40}$. Oprócz negatywnych zjawisk generowanych przez przyczyny natury gospodarczej, wzmocnionych w wyniku globalnego kryzysu

37 Idem, Looking Forward: Some Comments on 'Perspectives', „PS: Political Science \& Politics” 2002, Vol. 35, No. 2, s. 274.

38 Krytykując niedemokratyczne reguły obowiązujące w strukturze APSA, pytał on wprost: „Dlaczego przytłaczającą większość przewodniczących APSA i składu redakcji APSR stanowią biali mężczyźni? A gdzie Afroamerykanie, Latynosi, kobiety, homoseksualiści, Azjaci - w skrócie, całe to zróżnicowane społeczeństwo Stanów Zjednoczonych i ten świat, do którego badania aspiruje APSA [...]?". Zob. The Idea, op.cit., s. 10.

39 Zob. P. Schwartz-Shea, A. Bennett, Introduction - Methodological Pluralism in Journals and Graduate Education? Commentaries on New Evidence, „PS: Political Science \& Politics” 2003, Vol. 36, No. 3, s. 371-372.

40 J.V. Scott, R.M. Smith, Teaching: The Issues Perestroika Neglected, „PS: Political Science \& Politics” 2010, Vol. 43, No. 4, s. 751-752. 
ekonomicznego, niepokój zwolenników Ruchu Pierestrojki budzi utrzymywanie się dotychczasowego status quo w zakresie ideologicznego układu sił w akademickiej politologii. Nie uległ on zasadniczym zmianom, co prowadzi do pesymistycznych wniosków na temat możliwości swobodnego wybierania własnych opcji badawczych i teoretycznych przez studentów i młodych naukowców. Stan ten dobrze ilustruje konstatacja Grega J. Kaszy: „Reforma edukacji magisterskiej jest podstawowym celem Ruchu Pierestrojki. Do czasu, gdy go nie osiągniemy, studenci będą znajdować się w trudnym położeniu. To bardzo ponura konstatacja, lecz obecnie, aby zostać godnym szacunku uczonym, w dużym stopniu będziesz musiał uczyć się sam"41.

Postulaty programowe zwolenników Ruchu Pierestrojki

\begin{tabular}{|c|c|}
\hline METODA & $\begin{array}{l}\text { (a) rzeczywiste równouprawnienie różnorodnych podejść oraz metod badawczych sto- } \\
\text { sowanych w politologii, zarówno tradycyjnych, związanych z klasyczną nauką o polityce, } \\
\text { jak i będących wynikiem rewolucji behawioralnej oraz pojawiających się współcześnie } \\
\text { (b) zrównoważenie znaczenia, pozycji i wpływu badań opartych na ujęciu ilościowym } \\
\text { i modelowaniu matematycznym z badaniami jakościowymi i opartymi na interpretacji } \\
\text { (c) odejście od oceniania rezultatów badawczych według kryteriów tzw. czystej nauki, } \\
\text { czyli standardów obowiązujących w naukach formalnych i przyrodniczych, opartych na } \\
\text { pozytywizmie logicznym i skrajnym naturalizmie }\end{array}$ \\
\hline TEORIA & $\begin{array}{l}\text { (a) rezygnacja z dążenia do stworzenia teorii ogólnej jako podstawowego paradygmatu } \\
\qquad \text { w nauce o polityce i innych naukach społecznych } \\
\text { (b) przywrócenie związków badań i wiedzy teoretycznej z rzeczywistymi problemami } \\
\text { życia politycznego, odejście od skrajnej hermetyczności i akademickości w stronę } \\
\text { związku nauki z praktyką } \\
\text { (c) akceptacja realnego pluralizmu ideowego w poszukiwaniach teoretycznych, nadanie } \\
\text { równorzędnej rangi badaniom zorientowanym na inne wartości niż konserwatywne } \\
\text { i skrajnie liberalne, m.in. teorii krytycznej, neomarksizmowi, multikulturalizmowi, } \\
\text { postmodernizmowi, feminizmowi }\end{array}$ \\
\hline
\end{tabular}

${ }^{41}$ G.J. Kasza, Unearthing the Roots of Hard Science: A Program for Graduate Students, [w:] Making Political Science Matter, op.cit., s. 233. 


\begin{tabular}{|c|c|}
\hline \multirow{1}{*}{$\begin{array}{c}\text { (a) demokratyzacja APSA, dopuszczenie do zarządzania Stowarzyszeniem środowisk } \\
\text { zmarginalizowanych ze względu na niedocenianie pewnych obszarów badawczych } \\
\text { i metod oraz z powodu nierówności pod względem etnicznym, kulturowym, rasowym } \\
\text { i płciowym }\end{array}$} \\
$\begin{array}{c}\text { ORGANI- } \\
\text { ZACJA / } \\
\text { STRUKTURA } \\
\text { wydawanych przez APSA i inne stowarzyszenia, opartych na otwartości redakcji i recen- } \\
\text { zentów na teksty o różnym profilu teoretycznym i metodologicznym }\end{array}$ \\
$\begin{array}{c}\text { (c) zwiększenie roli politologów w życiu społecznym, zatrzymanie postępującej izolacji } \\
\text { środowiska od realnych problemów politycznych i udziału w ocenianiu strategii i działań } \\
\text { polityków, uświadamianie im odpowiedzialności związanej z podejmowanymi decyzjami }\end{array}$ \\
$\begin{array}{c}\text { (d) wprowadzenie rzeczywistego pluralizmu w treściach i metodach kształcenia akade- } \\
\text { mickiego z zakresu politologii, otwierającego szanse studentom i młodym naukowcom } \\
\text { reprezentującym zainteresowania mieszczące się w różnych nurtach teoretycznych }\end{array}$ \\
\hline
\end{tabular}

Podobnie jak istniejący już ponad 40 lat Caucus for a New Political Science, który wystąpił z negatywną oceną behawioralnej wiedzy o polityce w okresie rewolucji lat sześćdziesiątych pod hasłem „uczynienia nauki o polityce przydatną w walce o lepszy świat”, tak i Ruch Pierestrojki motywował swoje cele ideą, by „politologia, jako akademicka dyscyplina, stała się znaczącym elementem współczesnej polityki”42. Oba bunty sformułowały mocno uzasadnione krytyczne oceny istniejącej sytuacji i zaproponowały programy reform zmierzające do zmiany sytuacji i budowy opartego na nowych zasadach konsensusu ${ }^{43}$. CNPS, mimo marginalnej pozycji w ramach APSA, przyczynił się do wyhamowania radykalnej fali rewolucji behawioralnej. W przypadku Ruchu Pierestrojki realne efekty działań organizacyjnych i programowych są widoczne jeszcze bardziej wyraźnie. Osiągnięte zostały one przez ruch niemający ram organizacyjnych i niezmierzający w kierunku bardziej jednoznacznego ukonstytuowania się. Fakt, że jest to bardzo luźna tendencja, skupiająca bardzo różnych zwolenni-

42 C. Barrow, The Intellectual Origins of New Political Science, „New Political Science” 2008, Vol. 30, No. 2, s. 215-216.

43 T.W. Luke, P.J. McGovern, The Rebels' Yell: Mr. Perestroika and the Causes of This Rebellion in Context, „PS: Political Science \& Politics” 2010, Vol. 43, No. 4, s. 731. 
ków - od renomowanych politologów po studentów, zbudowana trochę jako towarzyska kawiarenka internetowa, budzi wątpliwości co do dalszych losów tego przedsięwzięcia. Uczestnicy Ruchu Pierestrojki mają tego świadomośćc4, licząc się z koniecznością wyboru między kontynuowaniem rewolucji w aktualnej formie a decyzją o ustrukturyzowaniu się i instytucjonalizacji. Ten drugi wariant oznaczać może wzmocnienie pozycji w APSA, lecz jednocześnie będzie zapewne końcem idei Ruchu w pierwotnym kształcie. Niezależnie od dalszych losów tej inicjatywy wszystko wskazuje na to, że rozpoczęta w 2000 roku dyskusja na temat metodologii, teorii i struktury organizacyjnej współczesnej amerykańskiej politologii będzie kontynuowana i będzie wywierać realny wpływ na stan wiedzy o polityce i miejsce dyscypliny w życiu społecznym. Byłoby niewątpliwie dobrze, gdyby doświadczenia te znalazły odbicie także w polskiej rzeczywistości, wzmacniając i pogłębiając niemal nieobecną dyskusję na temat kwestii podstawowych dla rozwoju naszej dyscypliny ${ }^{45}$. Trudno bowiem rzetelnie i skutecznie poznawać naukowo świat, działając bezrefleksyjnie, z nastawieniem na wąskie cele, skupiając się na rozwiązywaniu problemów bieżących, bez stawiania sobie pytań o to, w jaki sposób i w jakim celu poszukujemy prawdy.

44 J.V. Scott, Ironic Representation, [w:] Perestroika!, op.cit., s. 277.

45 Od reguły są oczywiście wyjątki, m.in. wieloletni projekt badawczy Zakładu Metodologii i Teorii Polityki Uniwersytetu Jagiellońskiego rozpoczęty w 2007 roku „Kim jesteś politologu?”, ogólnopolskie konferencje: „Czym jest teoria w politologii?” (2010) Zakładu Teorii Polityki Wydziału Nauk Politycznych i Dziennikarstwa Uniwersytetu im. Adama Mickiewicza w Poznaniu i „Od nauk politycznych do nauki o polityce. Ewolucja i współczesny stan badań polityki” (2014) Instytutu Nauk Politycznych i Dziennikarstwa Uniwersytetu Śląskiego. 